\title{
Description of Volutoconus hargreavesi calcarelliformis subsp. nov. (Mollusca: Volutidae) from northwestern Australia
}

\author{
Fred E.Wells and Hugh Morrison \\ Department of Aquatic Zoology \\ Western Australian Museum \\ Perth, Western Australia 6000, Australia
}

\begin{abstract}
Volutoconus hargreavesi calcarelliformis subsp. nov. is described from the outer continental shelf off Port Hedland, northwestern Australia. The new subspecies is compared with $V$. hargreavesi hargreavesi (Angas, 1872), and $V$. hargreavesi daisyae Weaver, 1967, which is recognised as a valid subspecies.
\end{abstract}

Keywords: Subspecies, volute, Volutoconus, Gastropoda, Volutidae, Western Australia

\section{INTRODUCTION}

The volute genus Volutoconus is a small group of five species which are restricted to northern Australia, adjacent areas of the east and west coasts of the continent, and eastern Indonesia. The type species, V. coniformis (Cox, 1871), occurs along the north coast of Western Australia from the Dampier Archipelago to the west Kimberley. Further north, $V$. bednalli (Brazier, 1878) extends across the north Kimberley to Torres Strait, Queensland and throughout the Timor Sea to eastern Indonesia, including Irian Jaya. Volutoconus grossi (Iredale, 1927) ranges southward along the east coast of Australia from Townsville, Queensland to Port Macquarie, New South Wales. Two subspecies are generally recognised: V. grossi grossi (Iredale, 1927), which occurs south from Keppel Bay, Queensland and V. grossi mcmichaeli Habe and Kosuge, 1966, which occurs further north in the Townsville area. The fourth species, V. hargreavesi Angas, 1872, occurs widely along the west coast of Western Australia, from Mandurah to North West Cape, and along the north coast as far as the western Kimberley. Another species, V. capricorneus, was described by Wilson (1972) from west of Point Cloates and provisionally placed in Volutoconus. The generic placement of the species has varied, but the most recent analysis (Willan, 1995) places it in Volutoconus.

Weaver (1967) described a geographical variant of Volutoconus hargreavesi as the subspecies $V$. hargreavesi daisyae, which occurs along the west coast of Western Australia from North West Cape south to about Mandurah. Weaver restricted the nominate subspecies, $V$. hargreavesi hargreavesi, to the north coast of the state. However, Weaver and DuPont (1970) subsequently reported that further collecting had narrowed the gap between the two forms, and that subspecies status was not justified. Wilson and Gillett (1971) retained the separation of the subspecies, but stated that the finding of intermediates might show that the separation was not warranted. Wilson (1994) later considered that there was no need to separate the two subspecies. Poppe and Goto (1992) separated the two, but as forms, which have no taxonomic standing.

Recent curation of the volutes in the collection of the Western Australian Museum has uncovered a deep-water subspecies in the $V$. hargreavesi complex, which is described here. In addition, $V$. hargreavesi daisyae is recognised as a valid subspecies.

Institutional acronyms: AMNH, American Museum of Natural History; DMNH, Delaware Museum of Natural History; NTM, Northern Territory Museum, WAM, Western Australian Museum.

\section{SYSTEMATICS}

\section{Family Volutidae}

\section{Genus Volutoconus Crosse, 1871}

Volutoconus Crosse, 1871: 306

\section{Type species}

Voluta coniformis Crosse, 1871, by original designation.

\section{Diagnosis}

(Adapted from Weaver and DuPont [1970]). Moderately large $(60$ to $130 \mathrm{~mm}$ ) volutes, solid, with a range of colour patterns. Spire variable, elevated 


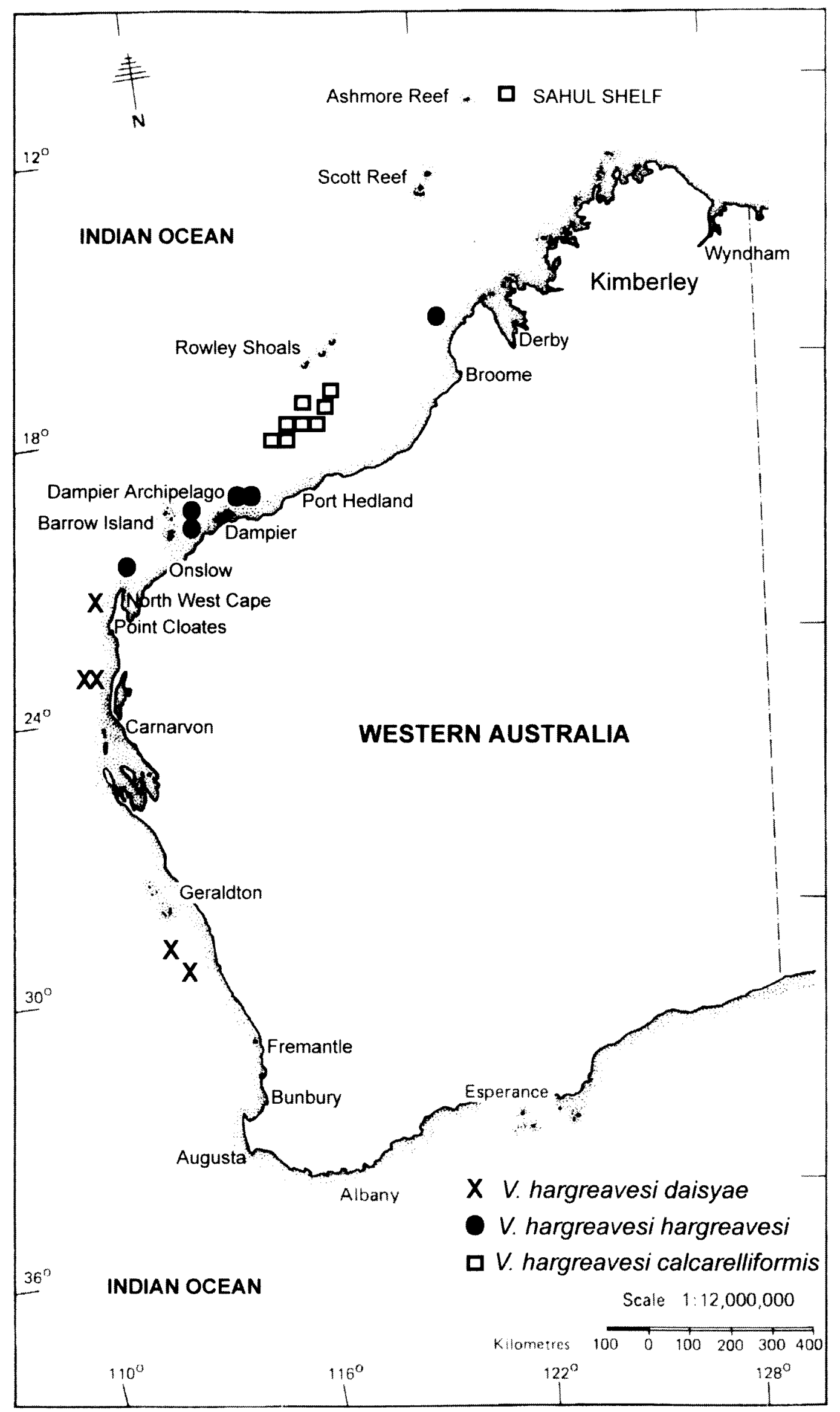

Figure 1 Distribution of Volutoconus hargreavesi calcarelliformis subsp. nov., V. hargreavesi hargreavesi (Angas, 1872), and $V$. hargreavesi daisyae Weaver, 1967. 


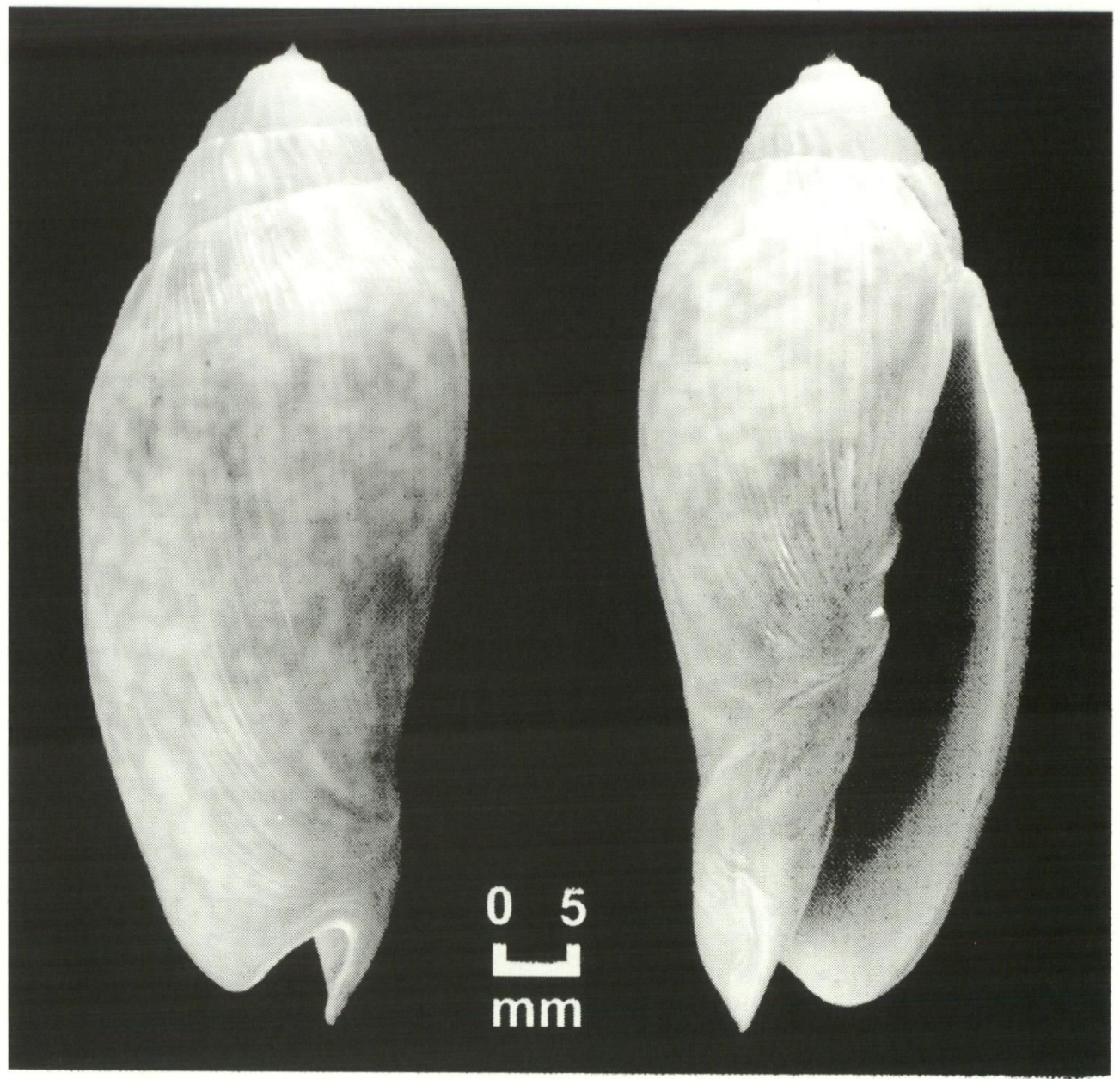

Plate 1 Holotype of Volutoconus hargreavesi calcarelliformis subsp. nov. (WAM S 14359)

or depressed. Protoconch smooth or radially ribbed, usually possessing a sharp apical spire (calcarella). Columella with four or more plaits. Periostracum and operculum absent. Radula (where known) uniserial, with large, tricuspid teeth, cusps strongly arched and fang like, median cusp much longer than laterals.

\section{Remarks}

The genus is restricted to northern Australia and Indonesia, ranging over the entire northern coastline of the continent, with individual species extending down both the west and east coasts. The systematics of Volutoconus have been examined in detail by Abbott (1958); McMichael (1960); Weaver (1967); Weaver and duPont (1970); Wilson and Gillett (1971); Wilson (1972; 1994) and Poppe and Goto (1992). The genus occurs from intertidal areas to at least $200 \mathrm{~m}$. Fossils previously included in the genus were considered to belong to Nannamoria by Darragh (1988). Darragh recorded only a single fossil specimen of an unidentified Volutoconus, which he considered to closely resemble $V$. hargreavesi.
Volutoconus hargreavesi hargreavesi (Angas, 1872) Plates 2c, 3c, Figure 1

Voluta hargreavesi Angas, 1872: 613-614, plate 42, figure 13 (locality unknown); Weaver, 1960: 1, 3 front page plate (4 shells on left); Weaver, 1967: 302 , 304, plate 41, figures 1-4, map; Weaver and duPont, 1970: 138, plate 61E-F; Matsukuma et al., 1991: p. 99, plate 97, figure 3; Poppe and Goto, 1992: 212, plate 107, figures 3-5, 7 .

Cymbiola (Volutoconus) hargreavesi (Angas): Abbott, 1958: 4

Volutoconus hargreavesi hargreavesi (Angas): Wilson and Gillett, 1971: 74, plate 49, figure 5.

\section{Type material}

Location of type unknown.

Weaver (1967) states the holotype is lodged in the American Museum of Natural History, number AMNH 8304. Weaver \& DuPont (1970) questioned whether this is in fact the holotype as there are differences between the colour pattern on the shell and the illustration.

The published catalogue of the AMNH (Boyko and 


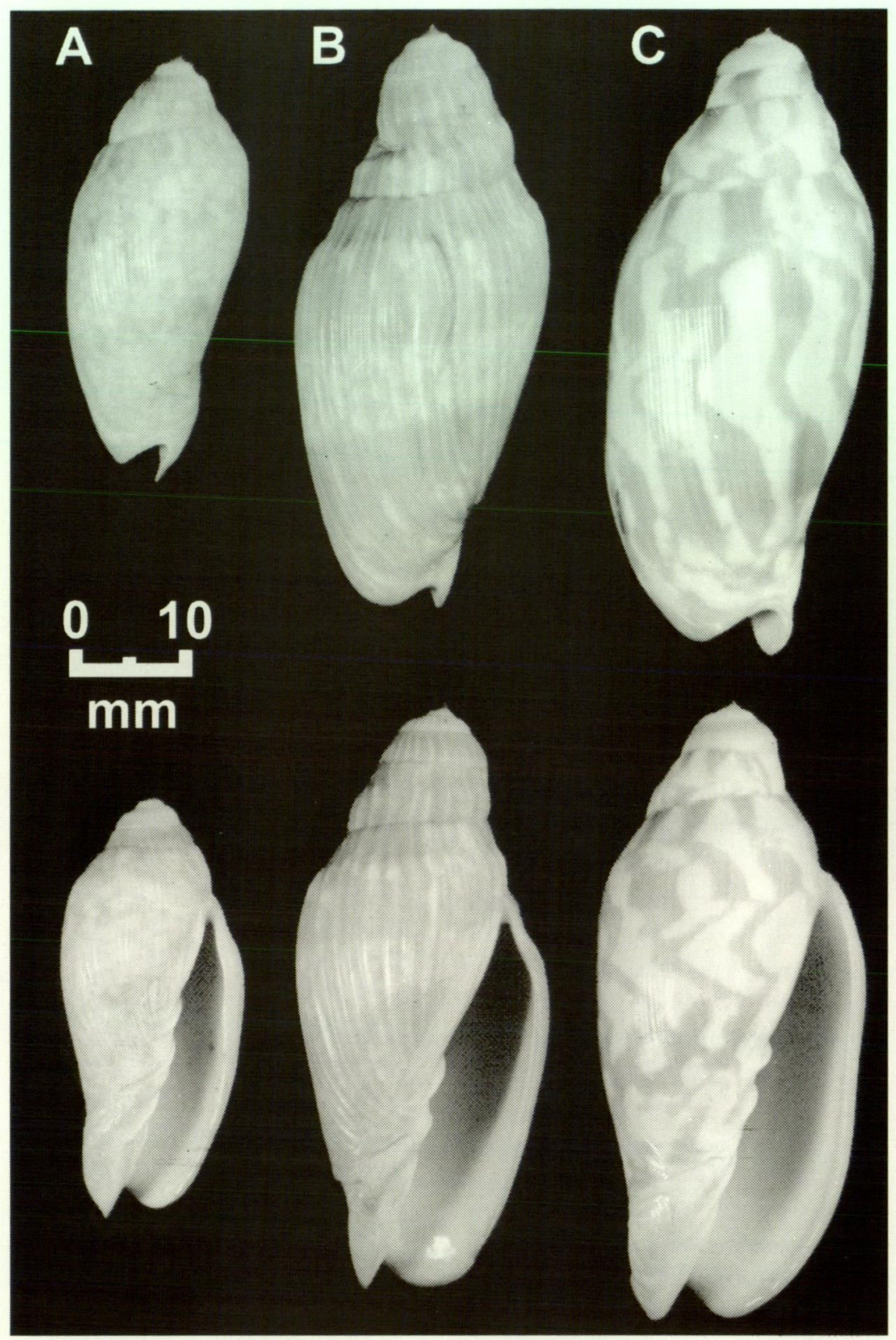

Plate 2 Comparison of shells of Volutoconus hargreavesi. a. Holotype of $V$. hargreavesi calcarelliformis subsp. nov. (WAM S 14359). b. V. hargreavesi daisyae Weaver, 1967 (WAM S 14358). c. V. hargreavesi hargreavesi (Angas, 1872) (WAM $S$ 14348).

Cordeiro, 2001) states: “AMNH 8304. ex Steward Collection \#1971. Richards and Old (1969: 117) summarized the limited information about this shell. They noted that it did not match exactly the size given by Angas (1872) for his unique specimen. $\mathrm{AMNH} 8304$ is the same size as the figure of the shell in Angas (1872: plate 42, figure 13) and matches the description. However, the AMNH shell is much more worn than suggested by Angas's (1872) figure, and the color pattern is quite different. Based on the available evidence, we are inclined to consider AMNH 8304 an old specimen of this taxon, but we think its holotype status is unlikely."

\section{Type locality}

Angas (1872) did not provide a type locality for
V. hargreavesi. Weaver (1960) subsequently designated Bedout Island in the Dampier Archipelago as the type locality.

Material examined: Australia: Western Australia: WAM S 14348, 2 specimens, NW of Roebuck Bay, S of Lacepedes Island (16 $52^{\circ}$ '; $\left.122^{\circ} 08^{\prime} \mathrm{E}\right) ;$ WAM S 14349,1 specimen, off Cape Lambert (20³6'S; $\left.117^{\circ} 10^{\prime} \mathrm{E}\right)$; WAM S 14350, 1 specimen, $26 \mathrm{~m}$, Dampier Archipelago, approximately $18 \mathrm{~km} \mathrm{~W}$ of Eaglehawk Island, (20³9'S;116²' $\mathrm{E})$; WAM S 14351, 1 specimen, 97 $\mathrm{m}$, Onslow, $13 \mathrm{~km} \mathrm{~N}$ of Long Island (2055'S;11551'E); WAM S 14352, 1 specimen, no data (seized by Australian Customs); WAM S 12669, 1 specimen, 103 m, North West Cape ( $\left.21^{\circ} 36.22^{\prime} \mathrm{S} ; 114^{\circ} 11.11^{\prime} \mathrm{E}\right)$, on sand and mud. 


\section{Diagnosis}

Calcarella small, orange colour, very finely ribbed. First two whorls of teleoconch white with very fine axial ribbing. Upper whorls with very fine ribbing. Body whorl with distinct, but fine ribbing. Colour variable, mottled orange and white, generally with 2 indistinct bands, one on shoulder of body whorl, one at base of whorl, sometimes a third intermediate band is present at base of body whorl. Four high, narrow columellar plaits. Anterior canal with deep notch, margin raised. Interior pale fawn to white.

\section{Range}

North West Cape to west Kimberley, Western Australia

\section{Depth range}

Intertidal to about $100 \mathrm{~m}$.

\section{Animal}

Not known.

\section{Remarks}

The three subspecies of $V$. hargreavesi are geographically distinct (Table 1). The nominate subspecies, $V$. hargreavesi hargreavesi, occurs along the continental coastline, from about North West Cape to the west Kimberley. Most specimens are from shallow water, but there are two lots in the WAM from about $100 \mathrm{~m}$. Volutoconus hargreavesi daisyae occurs further to the south, along the west coast of Western Australia, from about Mandurah to North West Cape, in depths of 40 to $134 \mathrm{~m}$. There is an area at North West Cape where the species ranges may or may not overlap. In contrast, $V$. hargreavesi calcarelliformis lives in deeper waters
(150-202 m) on the North West Shelf from the Rowley Shoals to Cartier Island.

Compared to $V$. hargreavesi calcarelliformis, $V$. hargreavesi hargreavesi has a smaller calcarella for the size of the shell. The shell of $V$. hargreavesi hargreavesi is bigger with a smoother surface. Volutoconus hargreavesi hargreavesi differs from $V$. hargreavesi daisyae in being a broader shell with fine growth lines instead of the more pronounced ribs found on $V$. hargreavesi daisyae.

\section{Volutoconus hargreavesi daisyae Weaver, 1967} Plates $2 b, 3 b$

Volutoconus "species" Angas, Weaver, 1960: 1, 3 front page plate (large centre shell).

Volutoconus hargreavesi daisyae Weaver, 1967: 302, 304, plate 41, figures 5-9, map; Wilson and Gillett, 1971: 74, plate 49, figure 6.

Volutoconus hargreavesi (Angas): Weaver and duPont, 1970: 138, plate 61G; Poppe and Goto, 1992: 212, plates 106, figure 1,2; Wells and Bryce, 1986: 118, figure 456; Wilson, 1994: 118, plate 21, figure 4 a-e.

\section{Type material}

Holotype, DMNH 10022.

\section{Type locality}

Southwest of North West Cape, central Western Australia, $22^{\circ} 00^{\prime} \mathrm{S} ; 113^{\circ} 45^{\prime} \mathrm{E}$.

\section{Material Examined}

Australia: Western Australia: WAM S 14355, 1

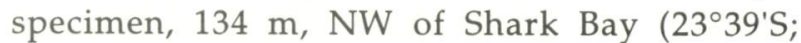
$\left.113^{\circ} 11^{\prime} \mathrm{E}\right) ;$ WAM S 14356, 1 specimen, $134 \mathrm{~m}, \mathrm{NW}$ of

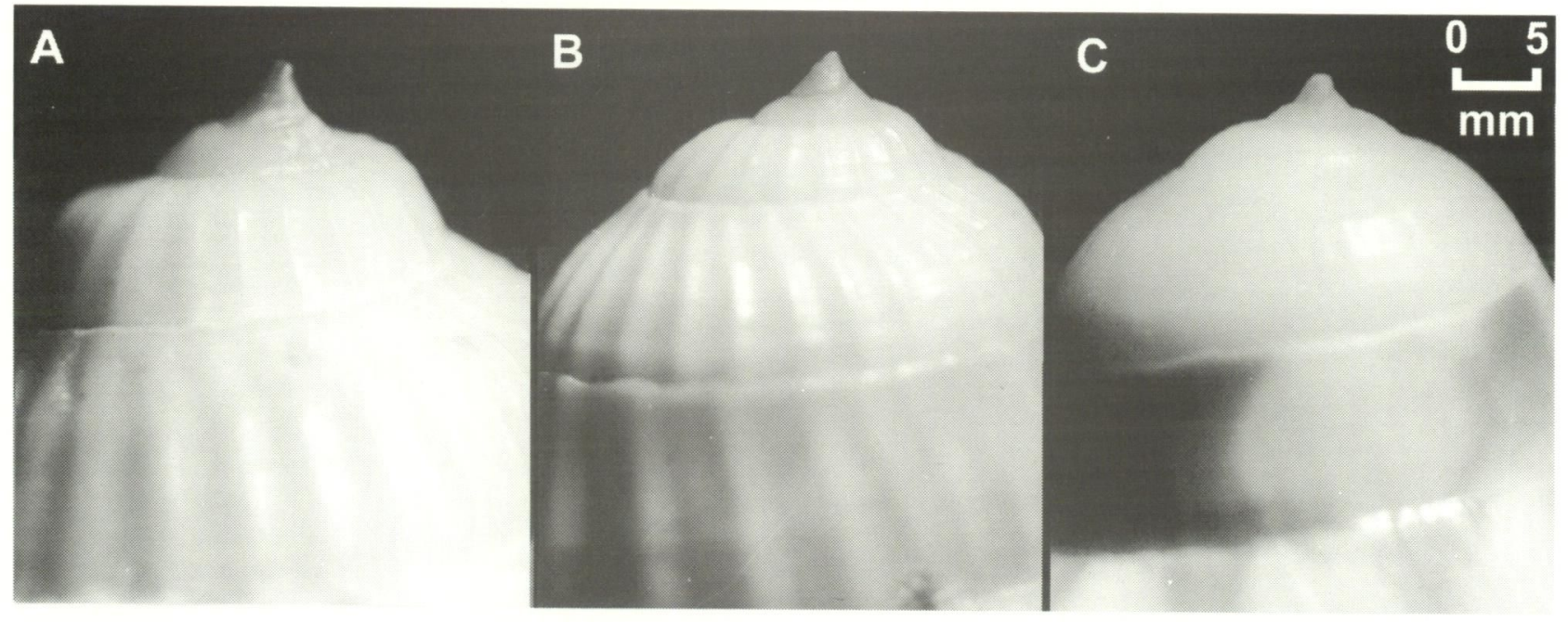

Plate 3 Comparison of protoconchs of Volutoconus hargreavesi. a. Holotype of $V$. hargreavesi calcarelliformis subsp. nov. (WAM S 14359). b. V. hargreavesi daisyae Weaver, 1967 (WAM S 14358). c. V. hargreavesi hargreavesi (Angas, 1872) (WAM S 14348). 
Shark Bay $\left(23^{\circ} 39^{\prime} S\right.$; $\left.113^{\circ} 11^{\prime} \mathrm{E}\right)$; WAM S 14357, 1 specimen, $110 \mathrm{~m}, 92 \mathrm{~km} \mathrm{~W}$ of Dongara $\left(29^{\circ} 07.5^{\prime} \mathrm{S}\right.$; $\left.113^{\circ} 57.4^{\prime} \mathrm{E}\right)$, sponges and stone rubble; WAM S 14358,1 specimen, off Greenhead $\left(30^{\circ} 04^{\prime} \mathrm{S}\right.$ $\left.114^{\circ} 58^{\prime} \mathrm{E}\right)$.

\section{Diagnosis}

Calcarella small, orange colour. Shell fusiform. First two whorls of teleoconch white with strong axial ribbing. Upper whorls with very strong ribbing extending onto body whorl. Body whorl heavily ribbed. Colour variable, mottled orange and white with 2 indistinct bands, one on upper body whorl, one lower on whorl. Four high, narrow columellar plaits. Anterior canal with deep notch, margin raised. Interior pale fawn to white.

\section{Range}

West coast of WA; Mandurah to North West Cape, Western Australia

\section{Depth}

Approximately $40 \mathrm{~m}$ to $134 \mathrm{~m}$.

\section{Animal \\ Not known.}

\section{Remarks}

Volutoconus hargreavesi daisyae differs from $V$. hargreavesi hargreavesi in having a narrower shell with pronounced axial ribbing instead of the fine growth lines found on $V$. hargreavesi hargreavesi. Volutoconus hargreavesi daisyae differs from $V$. hargreavesi calcarelliformis in being longer, more robust, with a similar protoconch, but a brighter orange colour. The ribs of $V$. hargreavesi daisyae are much heavier.

\section{Volutoconus hargreavesi calcarelliformis subsp. nov. \\ Plates 1, 2a and 3a}

\section{Holotype}

WAM S 14359, 150-160 m, $239 \mathrm{~km} \mathrm{NE}$ of Cape Lambert $\left(18^{\circ} 42.8^{\prime} \mathrm{S} ; 118^{\circ} 03.2^{\prime} \mathrm{E}\right)$, Western Australia, Australia, sand, rubble and dead shells, collected by L.M. Marsh et. al. on 18 August 1995.

\section{Paratypes}

Australia: Western Australia: WAM S 14360, 6 specimens, 173-193 m, $70 \mathrm{~km} \mathrm{~S}$ of Cunningham Island, Imperieuse Reef, Rowley Shoals (18 $06.9^{\prime} \mathrm{S}$; $\left.118^{\circ} 56.7^{\prime} \mathrm{E}\right)$, sand, rubble and dead shells; WAM S 14361, 5 specimens, $150-160 \mathrm{~m}, 239 \mathrm{~km}$ NE of Cape Lambert $\left(18^{\circ} 42.8^{\prime} \mathrm{S} ; 118^{\circ} 03.2^{\prime} \mathrm{E}\right)$, rubble and dead shells; WAM S 14362, 1 specimen, $150-160$ m, 239 $\mathrm{km}$ NE of Cape Lambert $\left(18^{\circ} 38.6^{\prime} \mathrm{S} ; 118^{\circ} 07^{\prime} \mathrm{E}\right)$, sand, rubble and dead shells; WAM S 14363, 2 specimens, $154 \mathrm{~m}, 184 \mathrm{~km} \mathrm{~N}$ of Port Hedland (18 $47^{\circ} \mathrm{S}$; $\left.117^{\circ} 58^{\prime} \mathrm{E}\right)$, grey mud and shell rubble; WAM $\mathrm{S}$ 14364, 2 specimens, $154 \mathrm{~m}, 184 \mathrm{~km} \mathrm{~N}$ of Port Hedland $\left(18^{\circ} 47^{\prime} \mathrm{S} ; 117^{\circ} 58^{\prime} \mathrm{E}\right)$, grey mud and shell rubble; WAM S 14365, 1 specimen, 201-202 m, 217 $\mathrm{km} \mathrm{N}$ of Port Hedland $\left(18^{\circ} 20.5^{\prime} \mathrm{S} ; 118^{\circ} 27.7^{\prime} \mathrm{E}\right)$, grey mud; WAM S 14389, 1 specimen, 150-160 m, 239 $\mathrm{km} \mathrm{NE}$ of Cape Lambert $\left(18^{\circ} 42.8^{\prime} \mathrm{S} 18^{\circ} 39.6^{\prime} \mathrm{S}\right)$, sand rubble and dead shells. NTM P8581, 1 specimen, $180 \mathrm{~m}, 20 \mathrm{~km}$ south of Barracouta Shoal, west of Cartier Reef, Sahul Shelf $\left(12^{\circ} 42.86 ' \mathrm{~S} ; 123^{\circ} 57.98^{\prime} \mathrm{E}\right)$, coarse broken shell substrate; Mike Claydon private collection, 1 specimen, trawled by scampi boats, on sand mud and shell, $220 \mathrm{~m}$, NW of Point Samson.

\section{Description}

Calcarella prominent, tall, smooth sided, lacking axial ribbing. Bright orange colour. First two whorls of teleoconch white, with strong axial ribbing. Lower whorls also heavily ribbed with mottled fawn to orange patterning. Body whorl finely ribbed, mottled brown with 3 faint bands, one below suture, one on outer body whorl, one lower on whorl. Four high, narrow columellar plaits. Anterior canal with deep notch. Interior white, some shells with pale fawn to white on inside of outer lip.

\section{Shell measurements}

Table 1 shows the measurements of the type series.

\section{Geographical range}

North West Shelf, Western Australia, from about Rowley Shoals to Cartier Island.

\section{Depth \\ 150-202 m.}

\section{Animal \\ Not known.}

\section{Etymology}

Named after the distinctive calcarella at the apex of the shell spire.

\section{Remarks}

The key feature of Volutoconus hargreavesi calcarelliformis is the prominent size of the calcarella for the size of the shell. It differs from $V$. hargreavesi hargreavesi in being smaller, with fine ribbing, strongly ribbed protoconch, and it lives in slightly deeper water. Volutoconus hargreavesi hargreavesi has a smoother shell with fine growth lines. Volutoconus hargreavesi calcarelliformis differs from $V$. hargreavesi daisyae in being shorter, more robust, with a similar protoconch, but a brighter orange colour. The ribs 


\begin{tabular}{|c|c|c|c|c|c|c|c|c|c|}
\hline \multirow[t]{2}{*}{ Species } & \multicolumn{2}{|c|}{ Range } & \multirow[t]{2}{*}{ Protoconch } & \multicolumn{2}{|l|}{ Teleoconch } & \multirow[b]{2}{*}{$\mathbf{N}$} & \multicolumn{3}{|c|}{ Shell measurements } \\
\hline & Geographic & Depth (m) & & Sculpture & $\begin{array}{l}\text { Plaits on } \\
\text { Columella }\end{array}$ & & $\begin{array}{l}\text { Length } \\
\text { (mm) } \\
\text { Mean } \\
\pm 1 \text { S.E. }\end{array}$ & $\begin{array}{l}\text { Width } \\
\text { (mm) } \\
\text { Mean } \\
\pm 1 \text { S.E. }\end{array}$ & $\begin{array}{l}\text { Length/ } \\
\text { Width } \\
\text { Mean } \\
\pm 1 \text { S.E. }\end{array}$ \\
\hline $\begin{array}{l}V . \text { hargreavesi } \\
\text { hargreavesi } \\
\text { (Angas, 1872) }\end{array}$ & $\begin{array}{l}\text { North coast } \\
\text { of WA; } \\
\text { North West } \\
\text { Cape to west } \\
\text { Kimberley }\end{array}$ & $0-201$ & $\begin{array}{l}\text { Small } \\
\text { calcarella, } \\
\text { orange colour, } \\
\text { finely ribbed. }\end{array}$ & $\begin{array}{l}\text { Shell broad, first two whorls of teloconch white } \\
\text { with with very fine axial ribbing. Upper whorls } \\
\text { with very fine ribbing. Body whorl with distinct, } \\
\text { but fine ribbing. Colour variable, mottled } \\
\text { orange and white, generally with } 2 \text { indistinct } \\
\text { bands, one on shoulder of body whorl, one at } \\
\text { base of whorl, sometimes a third intermediate } \\
\text { band is present at base of body whorl. Four } \\
\text { high, narrow columellar plaits. Anterior canal } \\
\text { with deep notch, margin raised. Interior pale } \\
\text { fawn to white. }\end{array}$ & $\begin{array}{l}4 \text { high, } \\
\text { narrow }\end{array}$ & 5 & $\begin{array}{r}18-105 \\
63 \pm 15\end{array}$ & $\begin{array}{c}8-37 \\
25 \pm 6\end{array}$ & $\begin{array}{c}2.17-2.84 \\
2.48 \pm 0.12\end{array}$ \\
\hline $\begin{array}{l}V . \text { hargreavesi } \\
\text { datsyae } \\
\text { Weaver, } 1968\end{array}$ & $\begin{array}{l}\text { West coast } \\
\text { of WA; } \\
\text { Mandurah to } \\
\text { North West } \\
\text { Cape }\end{array}$ & $0-134$ & $\begin{array}{l}\text { Small } \\
\text { calcarella, } \\
\text { orange colour }\end{array}$ & $\begin{array}{l}\text { Shell fusiform. First two whorls of teloconch } \\
\text { with strong axial ribbing, white. Upper whorls } \\
\text { with very strong ribbing extending onto body } \\
\text { whorl. Colour mottled orange and white. Body } \\
\text { whorl heavily ribbed. Colour variable, mottled } \\
\text { orange and white with } 2 \text { indistinct bands, one } \\
\text { on outer body whorl, one lower on whorl. } \\
\text { Anterior canal with deep notch, margin raised. } \\
\text { Interior pale fawn to white. }\end{array}$ & $\begin{array}{l}4 \text { high, } \\
\text { narrow }\end{array}$ & 3 & $\begin{array}{l}76-78 \\
77 \pm 1\end{array}$ & $\begin{array}{l}28-32 \\
30 \pm 1\end{array}$ & $\begin{array}{c}2.38-2.78 \\
2.61 \pm 0.12\end{array}$ \\
\hline $\begin{array}{l}\text { V. hargreavesi } \\
\text { calcarellaformis } \\
\text { subsp. nov. }\end{array}$ & $\begin{array}{l}\text { North West } \\
\text { Shelf, W.A. }\end{array}$ & $150-202$ & $\begin{array}{l}\text { Tiny } \\
\text { calcarella, } \\
\text { smooth sided, } \\
\text { tall, lacks } \\
\text { axial ribbing. } \\
\text { Bright orange } \\
\text { colour. }\end{array}$ & $\begin{array}{l}\text { First two whorls of teloconch with strong axial } \\
\text { ribbing, white. Lower whorls also heavily ribbed } \\
\text { with a mottled fawn to orange patterning. Body } \\
\text { whorl finely ribbed, mottled brown with } 3 \\
\text { faint bands, one below suture, one on outer } \\
\text { body whorl, one lower on whorl. Anterior canal } \\
\text { with deep notch. Interior white, some with pale } \\
\text { fawn to white on inside of outer lip. }\end{array}$ & $\begin{array}{l}4 \text { high, } \\
\text { narrow }\end{array}$ & 14 & $\begin{array}{l}38-64 \\
50 \pm 2\end{array}$ & $\begin{array}{l}16-26 \\
21 \pm 1\end{array}$ & $\begin{array}{c}2.14-2.94 \\
2.41 \pm 0.05\end{array}$ \\
\hline
\end{tabular}


of $V$. hargreavesi daisyae are much stronger than those of $V$. hargreavesi calcarelliformis.

The dwarf form of $V$. grossi (Iredale, 1927) from deep water off the Great Barrier Reef, Queensland, is very similar to $V$. hargreavesi calcarelliformis. Further material is required before the relationships between $V$. grossi and $V$. hargreavesi can be fully understood. In addition to the considerable geographic separation with a shallow water barrier between them, dwarf specimens of $V$. grossi can be separated from $V$. hargreavesi calcarelliformis by having a narrower shell and finer ribbing, and white calcarella.

\section{ACKNOWLEDGEMENTS}

We are grateful to $\mathrm{Dr}$ Richard Willan for information on the new subspecies, and Mike Claydon for the loan of material of the new subspecies. Clay Bryce was kind enough to photograph the specimens. We are pleased to acknowledge discussions with Dr Patrice Bail, Glad Hansen, Alan Limpus, and Dr Barry Wilson. Corey Whisson databased the specimens and assisted with preparation of the figure and plates. Drs Tom Darragh and Richard Willan very kindly reviewed the maunscript.

\section{REFERENCES}

Abbott, R.T. (1958). Notes on the anatomy of the Australian volutes, bednalli and grossi. Journal of the Malacological Society of Australia 1(2): 2-7.

Angas, G.F. (1872). Description of a new species of Voluta. Proceedings of the Zoological Society of London 1872: $613-614$.

Boyko, C.B. and Cordeiro, J. (2001). Catalog of Recent Type Specimens in the Division of Invertebrate Zoology, American Museum of Natural History. V. Mollusca Part 2 (Class Gastropoda [exclusive of Opisthobranchia and Pulmonata], with Supplements to Gastropoda [Opisthobranchia], and Bivalvia). Bulletin of the American Museum of Natural History 262: $1-170$.

Brazier, John. (1878). Descriptions of seven new species of terrestrial and marine shells from Australia. Proceedings of the Zoological Society of London 1878: 2023.
Cox, J.C. (1871). Description de deux espèces novelles de Voluta et observations sur le $V$. punctata Swainson. Journal de Conchyliologie 3(19): 74-77.

Crosse, J.C.H. (1871). Distribution géographique et catalogue des espèces actuelles du genre Voluta. Journal de Conchyliologie 14: 105-117.

Darragh, T.A. (1988). A revision of the Tertiary Volutidae (Mollusca: Gastropoda) of south-eastern Australia. Memoirs of the Museum of Victoria 49: 195-307.

Iredale, T. (1927). Caloundra shells. The Australian Zoologist 4: 336.

McMichael, D.F. (1960). Notes on some Australian Volutidae. Journal of the Malacological Society of Australia 1(4): 4-13.

Matsukuma, A., Okutani, T., and Habe, T. (1991). World Seashells of Rarity and Beauty. National Science Museum, Tokyo.

Poppe, G.T. and Goto, Y. (1992). Volutes. Mostra Mondiale Malacologia, Cupra Marittima (AP- Italy).

Richards, M.C. and Old, W.E. Jr. (1969). A catalogue of molluscan type specimens in the Department of Living Invertebrates, the American Museum of Natural History. American Museum of Natural History, New York. Unpublished report, $147 \mathrm{pp}$.

Weaver, C.S. (1960). Hawaiian scientific expedition finds rare Australian volutes. Hawaiian Shell News 8(10): 1,3.

Weaver, C.S. (1967). A new subspecies of Volutoconus hargreavesi (Angas, 1872) from central Western Australia. The Veliger 9(3): 301-304.

Weaver, C.S. and duPont, J.E. (1970). The Living Volutes. A monograph of the Recent Volutidae of the world. Delaware Museum of Natural History, Monograph Series No. 1: 1-375.

Wells, F.E. and Bryce, C.W. (1986). Seashells of Western Australia. Western Australian Museum, Perth.

Willan, R.C. (1995). Taxonomic and biogeographic review of the Australian endemic genus Nannamoria (Gastropoda: Volutidae) with the description of a new bathyal species. Invertebrate Taxonomy 9: 107-113.

Wilson, B.R. (1972). New species and records of Volutidae (Gastropoda) from Western Australia. Journal of the Malacological Society of Australia 2(3): 339360.

Wilson, B.R. (1994). Australian Marine Shells. Volume 2. Odyssey Publishing, Kallaroo, Western Australia.

Wilson, B.R. and Gillett, K. (1972). Australian Shells. A.H. and A.W. Reed, Sydney.

Manuscript received 29 April 2003; accepted 29 July 2003 